\title{
Metal-Mediated Addition of N-Nucleophiles to Isocyanides: Mechanistic Aspects
}

\author{
Maxim L. Kuznetsov ${ }^{1,2, *}$ and Vadim Yu. Kukushkin ${ }^{2}$ \\ 1 Centro de Química Estrutural, Instituto Superior Técnico, Universidade de Lisboa, Av. Rovisco Pais, Lisbon \\ 1049-001, Portugal \\ 2 International Group on Organometallic Chemistry, Institute of Chemistry, Saint Petersburg State University, \\ Universitetskaya Nab., 7/9, Saint Petersburg 199034, Russia; v.kukushkin@spbu.ru \\ * Correspondence: max@mail.ist.utl.pt; Tel.: +351-218-419-236
}

Received: 21 June 2017; Accepted: 6 July 2017; Published: 8 July 2017

\begin{abstract}
Despite the long history of the investigation of nucleophilic addition to metal-bound isocyanides, some important aspects of the reaction mechanism remain unclear even for the simplest systems. In this work, the addition of the $\mathrm{sp}^{3}-\mathrm{N}, \mathrm{sp}^{2}-\mathrm{N}$, and mixed $\mathrm{sp}^{2} / \mathrm{sp}^{3}-\mathrm{N}$ nucleophiles (i.e., $\mathrm{HNMe}_{2}, \mathrm{HN}=\mathrm{CPh}_{2}$, and $\mathrm{H}_{2} \mathrm{~N}-\mathrm{N}=\mathrm{CPh}_{2}$, respectively) to isocyanides $\mathrm{C} \equiv \mathrm{NR}$ coordinated to the platinum(II) centers in the complexes cis-[Pt(C $\equiv \mathrm{NCy})(2-\mathrm{pyz})(\mathrm{dppe})]^{+}(2-\mathrm{pyz}=2$-pyrazyl, dmpe $\left.=\mathrm{Me}_{2} \mathrm{PCH}_{2} \mathrm{CH}_{2} \mathrm{PMe}_{2}\right)$ and cis- $\left[\mathrm{PtCl}_{2}(\mathrm{C} \equiv \mathrm{NXyl})(\mathrm{C} \equiv \mathrm{NMe})\right]$ was studied in detail by theoretical (DFT) methods. The mechanism of these reactions is stepwise associative rather than concerted and it includes the addition of a nucleophile to the isocyanide $\mathrm{C}$ atom, deprotonation of the nucleophilic moiety in the resulting intermediate, and protonation of the isocyanide $\mathrm{N}$ atom to give the final product. The calculated activation energy $\left(\Delta \mathrm{G}^{\neq}\right)$of all reactions is in the range of $19.8-22.4 \mathrm{kcal} / \mathrm{mol}$.
\end{abstract}

Keywords: isocyanides; nitriles; nucleophilic addition; DFT calculations; activation of small molecules; reaction mechanism; carbenes

\section{Introduction}

Isocyanides $(\mathrm{C} \equiv \mathrm{NR})$ are highly demanding reagents toward materials with valuable properties [1-3] and they have a broad application in multicomponent [4-12] and insertion [4,13-18] reactions, catalysis [4,13,14,19-22], and polymer chemistry [15]. One of the most important types of the reactivity involving isocyanides is nucleophilic addition (NA) at the carbon atom of the $\mathrm{C} \equiv \mathrm{N}$ group (Scheme 1). This reaction is one of the most efficient and promising methods for the synthesis of heteroatom stabilized carbenes-species of superior importance exhibiting valuable biological [23,24], catalytic [19,25-39], and photophysical [40-43] properties. These reactions typically require the presence of a metal center to activate $\mathrm{C} \equiv \mathrm{NR}$. The first metal-mediated reaction of $\mathrm{C} \equiv \mathrm{NR}$ species was observed more than 100 years ago by Tschugajeff (Chugaev) and Skanawy-Grigorjewa [44,45]. As a result of the interaction between $\mathrm{K}_{2}\left[\mathrm{PtCl}_{4}\right]$ and $\mathrm{C} \equiv \mathrm{NMe}$ and the following addition of hydrazine, the first complex of a heteroatom-stabilized carbene was obtained [46-49]. Since that time, the metal-mediated addition of the monofunctional O- [50-54], N- [34-37,41,43,51-70], and other [71-78] nucleophiles as well as bifunctional nucleophiles $[27,34,53,62,64,79-89]$ to isocyanides was broadly investigated [1-3,90,91].

The $\mathrm{N}-\mathrm{H}$ nucleophiles with the $\mathrm{sp}^{3}$ type of the nitrogen orbital hybridization (e.g., amines and hydrazines) are among the most common reagents used in this reaction, and their addition to $\mathrm{C} \equiv \mathrm{NR}$ has been intensively exploring over several decades [34-37,41,43,51-70,92], including the experimental kinetic studies [93,94]. However, surprisingly, despite the long history of these researches, some important aspects of the reaction mechanism still remain unknown, even for the simplest systems. First, the experiments indicate the negative activation entropy and, therefore, the associative general 
type of the mechanism for the NA of amines to metal-bound isocyanides and the bimolecular rate limiting step of this reaction. Meanwhile, experimental results cannot discriminate the concerted $\left(\mathrm{I}_{\mathrm{a}}\right)$ and stepwise $(\mathrm{A})$ mechanism of the nucleophilic attack - both of them exhibiting the associative activation mode [93,94]. Second, the addition of $\mathrm{N}-\mathrm{H}$ nucleophiles of the $\mathrm{sp}^{2}-\mathrm{N}$ type (imines [95]) or the mixed $\mathrm{sp}^{2} / \mathrm{sp}^{3}-\mathrm{N}$ type, such as hydrazones [32], to metal-bound isocyanides was reported only recently and, to the best of our knowledge, no mechanistic studies of these processes were undertaken. Third, hydrazones bear two nucleophilic centers which may competitively participate in the NA to $\mathrm{C} \equiv \mathrm{NR}$. However, in contrast to the $\mathrm{sp}^{3}-\mathrm{N}$ bifunctional nucleophiles, no analysis of the regioselectivity from the mechanistic point of view was done in this case.

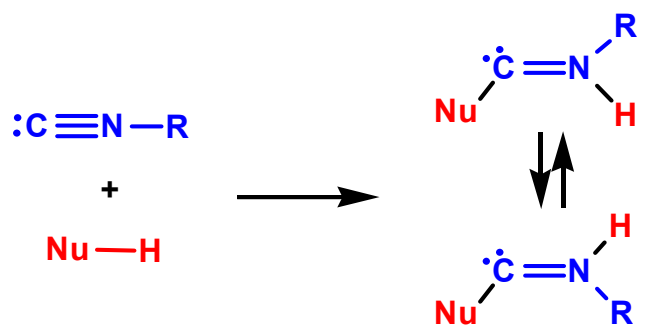

Scheme 1. Addition of nucleophile $\mathrm{Nu}-\mathrm{H}$ to isocyanides (formal charges are omitted).

The main goal of this work is to fill this gap in the understanding of the intimate mechanism of the NA of N-H nucleophiles to metal-bound isocyanides. The reactions of three $\mathrm{N}-\mathrm{H}$ nucleophiles of the $\mathrm{sp}^{3}-\mathrm{N}, \mathrm{sp}^{2}-\mathrm{N}$, and $\mathrm{sp}^{2} / \mathrm{sp}^{3}-\mathrm{N}$ type $\left(\mathrm{HNR}_{2}, \mathrm{HN}=\mathrm{CPh}_{2}\right.$, and $\mathrm{H}_{2} \mathrm{~N}-\mathrm{N}=\mathrm{CPh}_{2}$, respectively) with

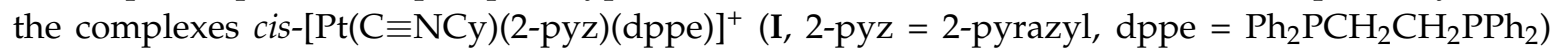
and $c i s-\left[\mathrm{PtCl}_{2}(\mathrm{C} \equiv \mathrm{NXyl})_{2}\right]$ (II) for which experimental data are available [32,93-95] were selected for this study. In the computational models, the dppe ligand was substituted by the dmpe ligand (dmpe $=\mathrm{Me}_{2} \mathrm{PCH}_{2} \mathrm{CH}_{2} \mathrm{PMe}_{2}$ ) and one of the $\mathrm{C} \equiv \mathrm{NXyl}$ ligands in II which remains unreacted was replaced for the $\mathrm{C} \equiv \mathrm{NMe}$ ligand.

\section{Computational Details}

The full geometry optimization of all structures and transition states (TSs) was carried out at the DFT level of theory by using the M06L functional [96] with the help of the Gaussian 09 [97] program package. No symmetry operations were applied. The geometry optimization was carried out by using a quasi-relativistic Stuttgart pseudopotential that describes 60 core electrons and the appropriate contracted basis set $(8 \mathrm{~s} 7 \mathrm{p} 6 \mathrm{~d}) /[6 \mathrm{~s} 5 \mathrm{p} 3 \mathrm{~d}]$ [98] for the platinum atom and the $6-31 \mathrm{G}^{*}$ basis set for other atoms. Single-point calculations were then performed on the basis of the equilibrium geometries found by using the $6-311+G^{* *}$ basis set for non-metal atoms. The solvent effects were taken into account in both optimization and single-point calculations using the SMD model [99] with dichloroethane (for reaction of complex 1) or chloroform (for reactions of complex 2) as solvents. If not stated otherwise, the energies discussed below are Gibbs free energies $G\left(6-311+G^{* *}\right)$ calculated as $\mathrm{G}\left(6-311+\mathrm{G}^{* *}\right)=\mathrm{E}\left(6-311+\mathrm{G}^{* *}\right)-\mathrm{E}\left(6-31 \mathrm{G}^{*}\right)+\mathrm{G}\left(6-31 \mathrm{G}^{*}\right)$ where the basis set used is indicated.

The Hessian matrix was calculated analytically for the optimized structures to prove the location of correct minima (no imaginary frequencies) or saddle points (only one imaginary frequency), and to estimate the thermodynamic parameters, with the latter calculated at $25^{\circ} \mathrm{C}$. The nature of all transition states was investigated by analysis of the vectors associated with the imaginary frequency and by the calculations of the intrinsic reaction coordinates (IRC) by using the method developed by Gonzalez and Schlegel [100-102]. The Wiberg bond indices [103] and atomic charges were computed by using the natural-bond orbital (NBO) partitioning scheme [104]. 


\section{Results and Discussion}

\subsection{Mechanisms of NA to Isocyanides}

There are three main types of the mechanisms for NA to isocyanides, i.e., concerted, dissociative, and associative (Scheme 2). The concerted mechanism involves one-step attack of a nucleophile ( $\mathrm{NuH})$ at the $\mathrm{C}$ atom of the $\mathrm{C} \equiv \mathrm{N}$ group accompanied by simultaneous $\mathrm{H}$-transfer to the isocyanide $\mathrm{N}$ atom. This mechanism includes one transition state which may be either 4-membered (a) or 6-membered (b) (Figure 1). In the latter case, either second molecule of the reagent or a solvent molecule directly participates in the formation of TS and plays the role of an H-transfer promoter.

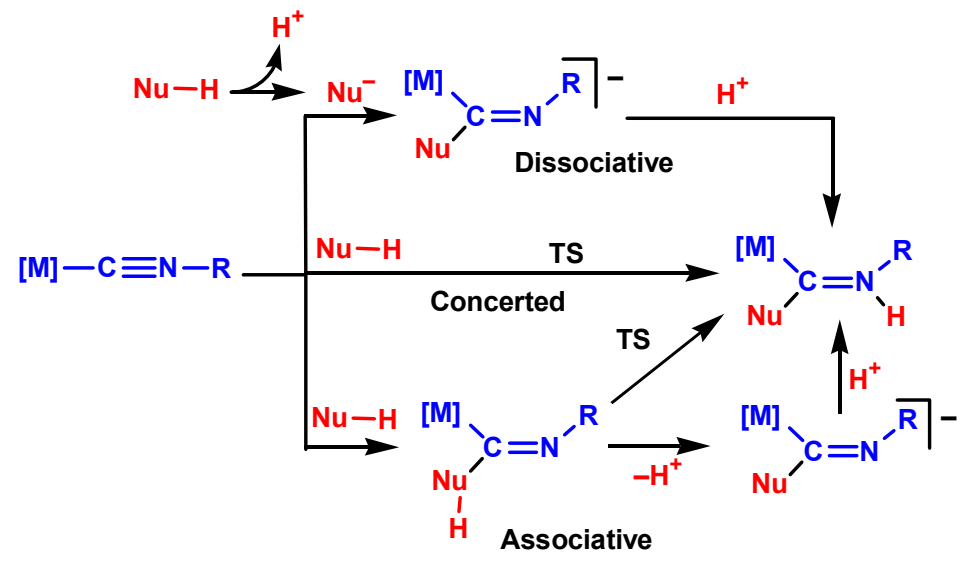

Scheme 2. Mechanisms of nucleophilic addition to metal-bound isocyanides (only one isomeric pathway is shown, formal charges are omitted).<smiles>[R]N1[IH][AlH]C1[N+]</smiles>

a<smiles>[Y][C]1[Y][Tl]NC([Y16])=[N+]1[R]</smiles>

b

\section{XH - proton shuttle}

Figure 1. Types of transition state of the concerted nucleophilic addition to metal-bound isocyanides.

The dissociative mechanism includes the initial deprotonation of $\mathrm{NuH}$, addition of the deprotonated fragment to the isocyanide $\mathrm{C}$ atom, and protonation of the isocyanide $\mathrm{N}$ atom. The deprotonation of $\mathrm{NuH}$ may be assisted by any base from the reaction mixture, e.g., water molecules often coming as moisture with organic solvents, nucleophilic additives or ligands or nucleophile itself.

The associative mechanism starts with the nucleophilic attack of $\mathrm{NuH}$ at the isocyanide $\mathrm{C}$ atom to give an acyclic intermediate which may be converted into the final product as a result of the proton transfer which, in turn, may be either concerted or stepwise.

\subsection{Reaction of the $s p^{3}-N$ Nucleophiles. Comparison with the Experimental Kinetic Data}

The simplest representatives of the $\mathrm{N}-\mathrm{H}$ nucleophiles featuring the $\mathrm{sp}^{3}$ hybridization of the nitrogen atom orbitals are amines. In this section, the reaction between dimethylamine $\mathrm{HNMe}_{2}$ and the isocyanide Pt complex cis-[Pt(C三NCy)(2-pyz)(dmpe) $]^{+}(\mathbf{1})$ is discussed. As was indicated in the Introduction, experimental kinetic data are available for the similar system $\mathrm{HNEt}_{2}$ + cis- $[\mathrm{Pt}(\mathrm{C} \equiv \mathrm{NCy})(2-\mathrm{pyz})(\mathrm{dppe})]^{+}$. Therefore, comparison of the calculated and experimental kinetic parameters allows the testing of the computational method and model used in this work. Additionally, some mechanistic features of this simple process still remain uncertain (see Introduction). 


\subsubsection{Concerted Mechanism}

The calculations revealed that the concerted mechanism is not realized for this process. Indeed, an extensive search of the potential energy surface (PES) indicated that there is no minimum corresponding to any of the TSs of the concerted mechanism. All attempts of its location led to TSs of the stepwise pathways discussed below. This result is different from that found previously for NA to nitriles $N \equiv C R$ for which both 4-membered and 6-membered cyclic TSs of the concerted NA were located [105].

\subsubsection{Dissociative Mechanism}

Within this mechanism, $\mathrm{H}_{2} \mathrm{O}, \mathrm{HNMe}_{2}$, and the pyrazine ligand in $\mathbf{1}$ were considered as bases for the initial proton abstraction from $\mathrm{HNMe}_{2}$ (reactions 1-3). The PCM-based solvation models often fail to estimate correctly solvent effects for processes, in which the number of species with the same charge is not preserved in the course of the reaction. Therefore, straightforward calculations of the $\Delta G_{s}$ values of reactions $1-3$ as a difference $\Sigma G_{s}$ (products) $-\Sigma G_{s}$ (reactants) is not appropriate. To study the possibility of realization of the dissociative mechanism, a scan of the potential energy surface with the fixed $\mathrm{N}-\mathrm{H}$ bond of $\mathrm{HNMe}_{2}$ and relaxed other bonds was undertaken for the systems $\mathrm{H}_{2} \mathrm{O} \cdots \mathrm{H}-\mathrm{NMe}_{2}$, $\mathrm{Me}_{2}(\mathrm{H}) \mathrm{N} \cdots \mathrm{H}-\mathrm{NMe}_{2}$, and $1 \cdots \mathrm{H}-\mathrm{NMe}_{2}$. The energy of the systems monotonously increases upon enhancement of the NH internuclear distance, demonstrating the absence of any TS for these processes (Figure 2). The lowest limits of the activation energy $E_{a, s}$ estimated from the energy curves are 97.6, 30.9 , and $43.3 \mathrm{kcal} / \mathrm{mol}$ for reactions $1-3$, respectively. Taking into account that the entropic factor is insignificant for these processes, the estimates for the $\Delta \mathrm{G}_{\mathrm{s}} \neq$ limits should also be close to these values. Thus, the dissociative mechanism may be ruled out due to inefficient deprotonation of the nucleophile.

$$
\begin{aligned}
\mathrm{HNMe}_{2}+\mathrm{H}_{2} \mathrm{O} & \rightarrow \mathrm{NMe}_{2}{ }^{-}+\mathrm{H}_{3} \mathrm{O}^{+} \\
\mathrm{HNMe}_{2}+\mathrm{HNMe}_{2} & \rightarrow \mathrm{NMe}_{2}{ }^{-}+\mathrm{H}_{2} \mathrm{NMe}_{2}{ }^{+} \\
\left.\left.\mathrm{HNMe}_{2}+\text { cis-[Pt(CNCy)(2-pyz)(dmpe }\right)\right]^{+} & \left.\rightarrow \mathrm{NMe}_{2}{ }^{-}+\text {cis-[Pt(CNCy)(2-pyzH)(dmpe) }\right]^{2+}
\end{aligned}
$$

\subsubsection{Associative Mechanism}

This pathway starts with the formation of the orientation van der Waals complexes OC1 between $\mathrm{HNMe}_{2}$ and 1 (Figure 3). The process is exothermic by $-5.8 \mathrm{kcal} / \mathrm{mol}$ but endoergonic by $6.5 \mathrm{kcal} / \mathrm{mol}$ due to unfavorable entropic factor. OC1 transforms into transition state TS1 corresponding to the formation of the $\mathrm{CN}$ bond between reactant molecules and then into the acyclic intermediate INT1.

The proton transfer INT1 $\rightarrow$ P1 may occur either in a concerted or in a stepwise manner. Four-membered TS2 of the concerted H-transfer was found, whereas no 6-membered transition state of this route was located. However, a high energy of TS2 relative to the level of initial reactants $(36.3 \mathrm{kcal} / \mathrm{mol})$ indicates that the pathway based on this TS is not realized.

The stepwise H-transfer in INT1 includes (i) energetically neutral formation of the orientation complex OC2 between INT1 and the second $\mathrm{HNMe}_{2}$ molecule, (ii) deprotonation of INT1 with $\mathrm{HNMe}_{2}$ via TS3 to give intermediate INT2 with very low activation barrier of $1.4 \mathrm{kcal} / \mathrm{mol}$ relative to OC2, and (iii) protonation of the isocyanide $\mathrm{N}$ atom by $\mathrm{H}_{2} \mathrm{NMe}_{2}{ }^{+}$via TS4 affording the final product P1. The Gibbs free energy of TS4 is lower than that of INT2. This phenomenon is accounted for by the fact that total energy of the system was minimized upon the geometry optimization rather than Gibbs free energy. Indeed, in terms of total energy, the $E_{S}$ value of TS2 is higher than that of INT2 by 0.7 $\mathrm{kcal} / \mathrm{mol}$. 

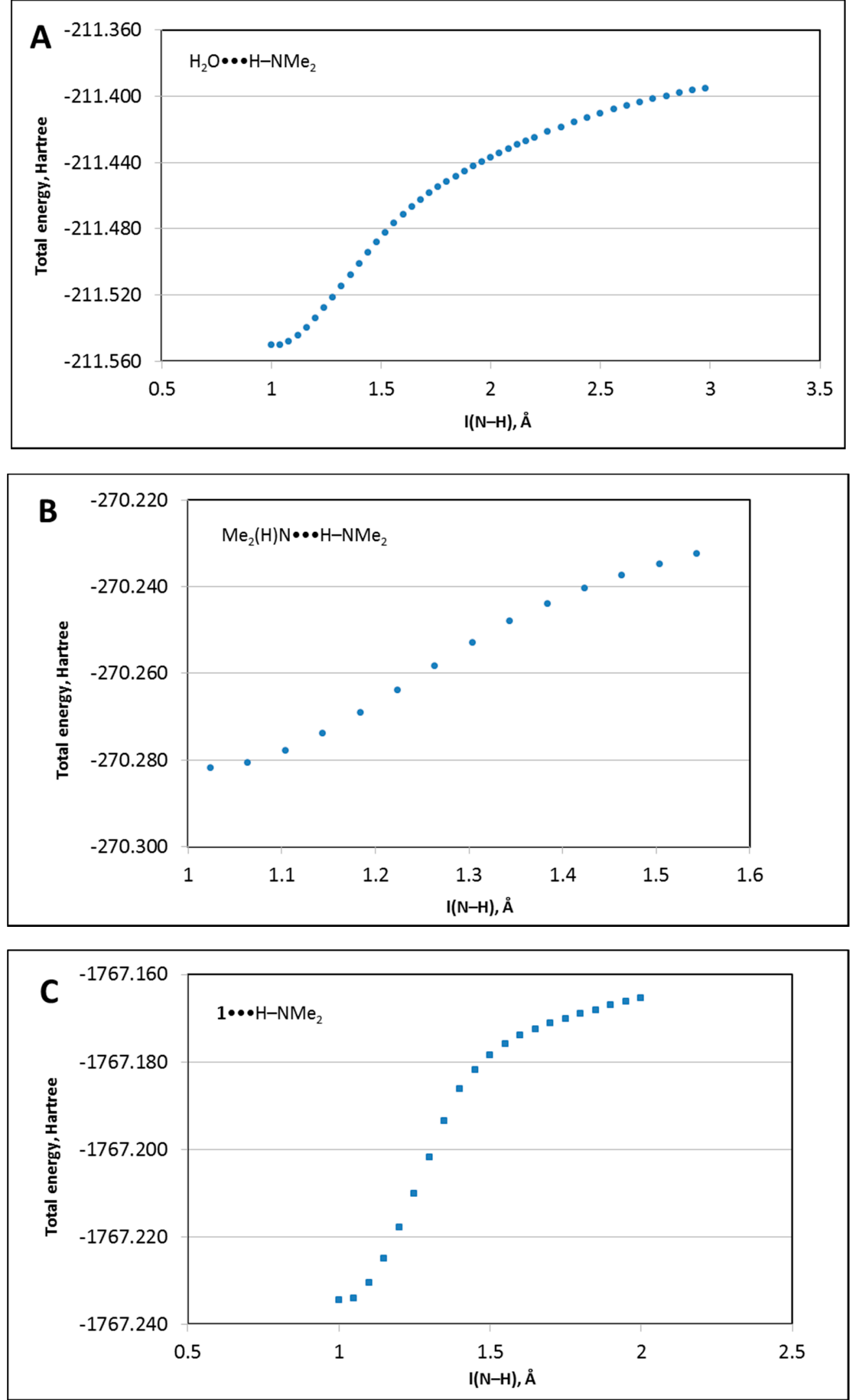

Figure 2. Total energy vs. the N-H distance in the systems $\mathrm{H}_{2} \mathrm{O} \cdots \mathrm{H}-\mathrm{NMe} \mathrm{N}_{2}(\mathbf{A}), \mathrm{Me}_{2}(\mathrm{H}) \mathrm{N} \cdots \mathrm{H}-\mathrm{NMe}_{2}$ (B), and $1 \cdots \mathrm{H}-\mathrm{NMe}_{2}(\mathbf{C})$. 


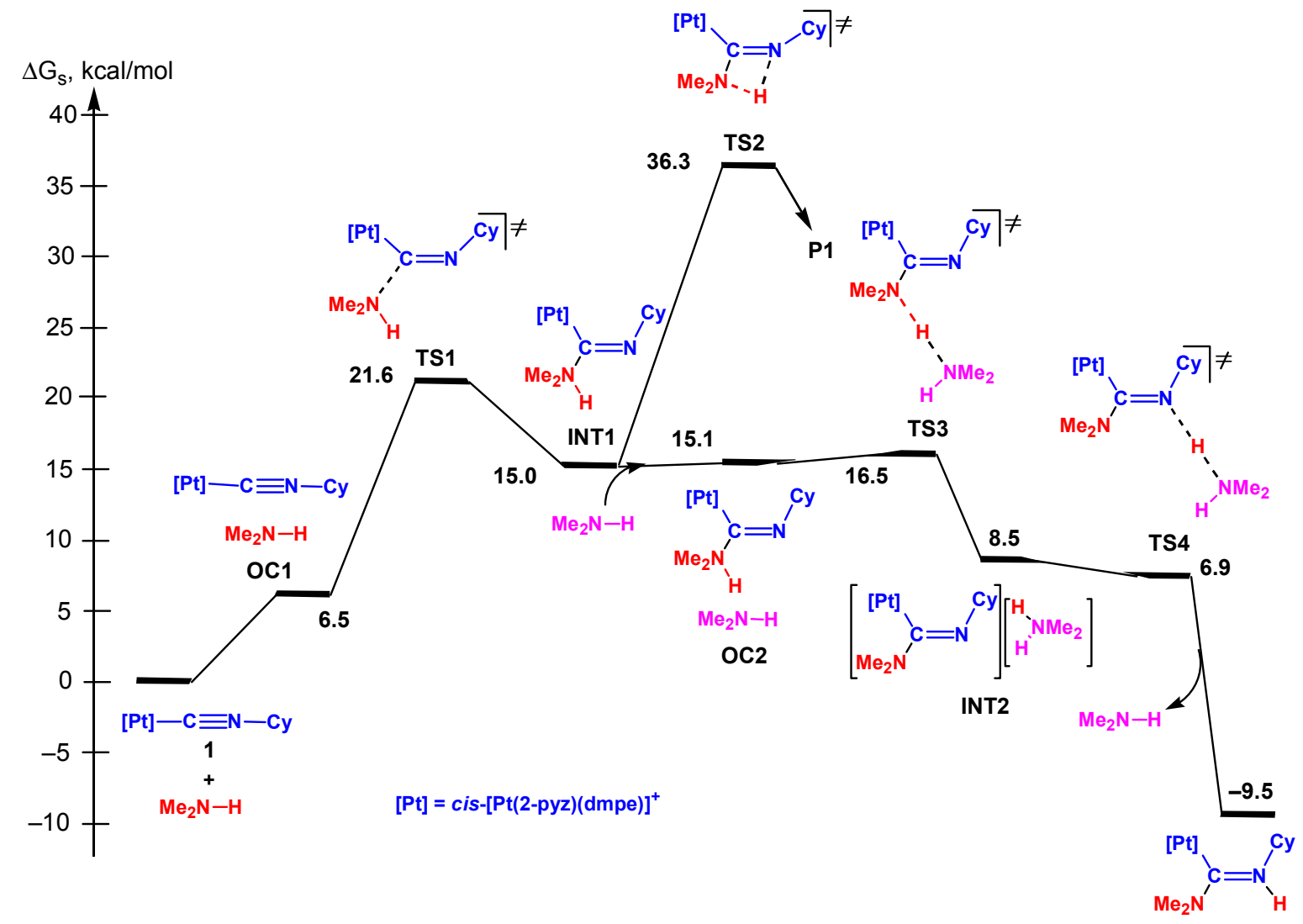

P1

Figure 3. Energy profile for the associative mechanism of the nucleophilic addition of $\mathrm{HNMe}_{2}$ to cis-[Pt(C $\equiv \mathrm{NCy})(2-\mathrm{pyz})(\mathrm{dmpe})]^{+}$.

Thus, the computational results indicate that the most plausible mechanism of the reaction between $\mathrm{HNMe}_{2}$ and $\mathbf{1}$ is of the stepwise associative type. The first nucleophilic attack is the rate limiting step, while the proton transfer in INT1 occurs very fast with assistance of the second nucleophile molecule. These theoretical predictions are in agreement with strongly negative experimental activation entropy value of $-43 \pm 3$ e.u. for the reaction $\mathrm{HNEt}_{2}+\mathbf{I}$. The calculated enthalpy and Gibbs free energy of activation $(6.9$ and $21.6 \mathrm{kcal} / \mathrm{mol})$ are in good agreement with the corresponding experimental values $7.0 \pm 0.8$ and $19.8 \pm 1.7 \mathrm{kcal} / \mathrm{mol}$ [93], thus validating the used computational method and model.

\subsection{Reactions of the $s p^{2}-N$ and $s p^{2} / s p^{3}-N$ Nucleophiles}

In this section, reactions of the $\mathrm{NH}$ nucleophiles with predominantly $\mathrm{sp}^{2}$ and intermediate between $\mathrm{sp}^{2}$ and $\mathrm{sp}^{3}$ types of the nitrogen orbital hybridization are discussed. Imines $\mathrm{HN}=\mathrm{CR}_{2}$ are the simplest representatives of the first group of $\mathrm{NuH}$, whereas hydrazones $\mathrm{R}^{\prime} \mathrm{HN}-\mathrm{N}=\mathrm{CR}_{2}$ are typical examples of the second group. The natural bond orbital (NBO) analysis of benzophenone hydrazone $\mathrm{H}_{2} \mathrm{~N}-\mathrm{N}=\mathrm{CPh}_{2}$ shows that hybridization of the amino nitrogen orbital forming the $\sigma-\mathrm{NBO}$ with the central $\mathrm{N}$ atom is $\mathrm{sp}^{2.5}$. Additions of benzophenone imine $\mathrm{HN}=\mathrm{CPh}_{2}$ and benzophenone hydrazone $\mathrm{H}_{2} \mathrm{~N}-\mathrm{N}=\mathrm{CPh}_{2}$ to the xylylisocyanide ligand in the complex cis-[ $\left.\mathrm{PtCl}_{2}(\mathrm{CNMe})(\mathrm{CNXyl})\right](2)$ were calculated as examples of these types of NA.

\subsubsection{Concerted and Dissociative Mechanisms}

Similarly to the previous case, no transition states of the concerted NA were found for the reactions of $\mathbf{2}$ with both the imine and the hydrazone. On the other hand, the lowest limits of the activation 
energy $E_{a, s}$ found for the proton dissociation from $\mathrm{HN}=\mathrm{CPh}_{2}$ or $\mathrm{H}_{2} \mathrm{NN}=\mathrm{CPh}_{2}$ are in the range of 29.0-65.3 kcal/ $\mathrm{mol}$ (reactions 4-7) (Figures S1 and S2 in Supplementary Material). The hydrazone appears to be a stronger acid than imine and a stronger base than water due to ambivalent character of this reagent. Thus, the dissociative pathway could be realized, in principle, only for the reaction of $\mathrm{H}_{2} \mathrm{~N}-\mathrm{N}=\mathrm{CPh}_{2}$ with 2 when another molecule of hydrazone plays the role of a base, while for the imine $\mathrm{HN}=\mathrm{CPh}_{2}$ this mechanism may be excluded.

$$
\begin{gathered}
\mathrm{HN}=\mathrm{CPh}_{2}+\mathrm{H}_{2} \mathrm{O} \rightarrow \mathrm{N}=\mathrm{CPh}_{2}{ }^{-}+\mathrm{H}_{3} \mathrm{O}^{+} \mathrm{E}_{\mathrm{a}, \mathrm{s}} \geq 65.3 \mathrm{kcal} / \mathrm{mol} \\
\mathrm{HN}=\mathrm{CPh}_{2}+\mathrm{HN}=\mathrm{CPh}_{2} \rightarrow \mathrm{N}=\mathrm{CPh}_{2}{ }^{-}+\mathrm{H}_{2} \mathrm{~N} \mathrm{CPh}_{2}{ }^{+} \mathrm{E}_{\mathrm{a}, \mathrm{s}} \geq 35.6 \mathrm{kcal} / \mathrm{mol} \\
\mathrm{H}_{2} \mathrm{~N}-\mathrm{N}=\mathrm{CPh} 2+\mathrm{H}_{2} \mathrm{O} \rightarrow \mathrm{HN}-\mathrm{N}=\mathrm{CPh}_{2}{ }^{-}+\mathrm{H}_{3} \mathrm{O}^{+} \mathrm{E}_{\mathrm{a}, \mathrm{s}} \geq 57.8 \mathrm{kcal} / \mathrm{mol} \\
\mathrm{H}_{2} \mathrm{~N}-\mathrm{N}=\mathrm{CPh}_{2}+\mathrm{H}_{2} \mathrm{~N}-\mathrm{N}=\mathrm{CPh}_{2} \rightarrow \mathrm{HN}-\mathrm{N}=\mathrm{CPh}_{2}{ }^{-}+\mathrm{H}_{2} \mathrm{~N}-\mathrm{N}(\mathrm{H})=\mathrm{CPh}_{2}{ }^{+} \mathrm{E}_{\mathrm{a}, \mathrm{s}} \geq 29.0 \mathrm{kcal} / \mathrm{mol}
\end{gathered}
$$

\subsubsection{Associative Mechanism}

This pathway includes the formation of orientation complexes OC3 and OC4, transition states associated with the $\mathrm{C}-\mathrm{N}$ bond creation (TS5 and TS10), and intermediates INT3 and INT5 (Figures 4 and 5). The further H-transfers INT3 $\rightarrow \mathbf{P 2}$ and INT5 $\rightarrow \mathbf{P 3}$ in these intermediates occur in a stepwise manner. The second molecule of NuH abstracts a proton from INT3 and INT5 to give deprotonated species INT4 and INT7. In these complexes, a nitrogen inversion in the bent isocyanide ligand should occur easily. Hence, there are two possible channels for the protonation of INT4 and INT7 leading either to Z-isomer or to $E$-isomer of the final products $\mathbf{P} 2$ and P3. The overall activation barriers for this pathway are 22.4 and $19.8 \mathrm{kcal} / \mathrm{mol}$ for the reactions of the imine and the hydrazone, respectively.

Besides, for these nucleophiles, both 4-and 6-membered cyclic transition states TS6, TS7, TS12, and TS13 of the concerted $\mathrm{H}$-transfer were also located. However, this mechanism is significantly less favorable than the stepwise proton shift (Figures 4 and 5).

\subsubsection{Nucleophilic Addition by the Imino N Atom of Hydrazone}

The hydrazone molecule $\mathrm{H}_{2} \mathrm{~N}-\mathrm{N}=\mathrm{CPh}_{2}$ has two nucleophilic centers, i.e., the amino and imino nitrogen atoms. Hence, the hydrazone may also attack the isocyanide carbon atom by another, imino nitrogen atom. The amino $\mathrm{N}$ atom has significantly higher negative effective $\mathrm{NBO}$ atomic charge than the imino $\mathrm{N}$ atom $(-0.67 \mathrm{vs}$. $-0.27 \mathrm{e})$. However, the imino $\mathrm{N}$ atom is a stronger nucleophile from the thermodynamic point of view. Among two protonated structures, $\mathrm{H}_{3} \mathrm{~N}-\mathrm{N}=\mathrm{CPh}_{2}{ }^{+}$and $\mathrm{H}_{2} \mathrm{~N}-\mathrm{N}(\mathrm{H})=\mathrm{CPh}_{2}{ }^{+}$, the latter is $5.9 \mathrm{kcal} / \mathrm{mol}$ more stable than the former. The corresponding intermediate INT6 was also found to be more stable than INT5 by $2.8 \mathrm{kcal} / \mathrm{mol}$ (Figure 5). However, transition state TS11 leading to INT6 is higher in energy than TS10 by $3.2 \mathrm{kcal} / \mathrm{mol}$ that correlates with the atomic charge distribution - one of the principal factors determining the kinetic of nucleophilic additions. Thus, the participation of the imino $\mathrm{N}$ atom in the reaction is less favorable and, therefore, other steps of this mechanism were not calculated.

\subsubsection{Mechanism Involving the Dipole Tautomeric form of Hydrazone}

The $\mathrm{H}$-transfer from the amino $\mathrm{N}$ atom to the imino nitrogen in the $\mathrm{H}_{2} \mathrm{~N}-\mathrm{N}=\mathrm{CPh}_{2}$ molecule leads to the dipole tautomeric form $\mathrm{HN}^{-}-\mathrm{N}^{+}(\mathrm{H})=\mathrm{CPh}_{2}$ and thus should enhance the nucleophilic properties of the terminal nitrogen atom. Indeed, the activation barrier for the $\mathrm{NA}$ of $\mathrm{HN}^{-}-\mathrm{N}^{+}(\mathrm{H})=\mathrm{CPh}_{2}$ to 2 is $15.3 \mathrm{kcal} / \mathrm{mol}$ vs. $19.8 \mathrm{kcal} / \mathrm{mol}$ for the $\mathrm{H}_{2} \mathrm{~N}-\mathrm{N}=\mathrm{CPh}_{2}$ form. However, the tautomerization is very endoergonic process (by $16.1 \mathrm{kcal} / \mathrm{mol}$ ) and, as a result, the overall activation barrier for this mechanism is much higher $(31.3 \mathrm{kcal} / \mathrm{mol}$, Figure 5$)$. 


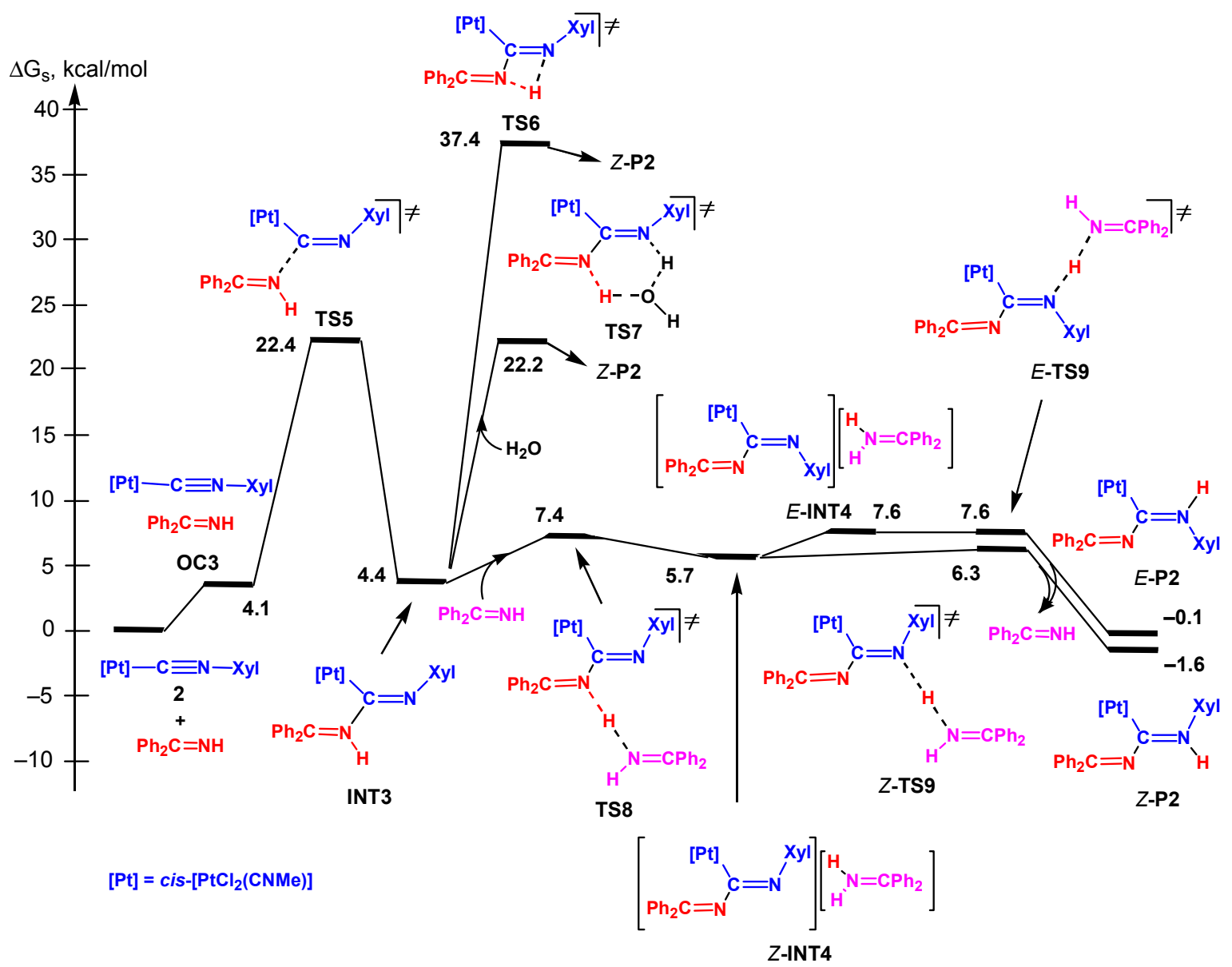

Figure 4. Energy profile for the associative mechanism of nucleophilic addition of $\mathrm{HN}=\mathrm{CPh}_{2}$ to the $\mathrm{C} \equiv \mathrm{NXyl}$ ligand in $c i s-\left[\mathrm{PtCl}_{2}(\mathrm{C} \equiv \mathrm{NMe})(\mathrm{C} \equiv \mathrm{NXyl})\right]$.

\subsubsection{Analysis of the Energy Profiles}

Analysis of the energy profiles for these reactions indicates the following (Figures 3-5). First, the most plausible mechanism is of the stepwise associative type. Second, in the case of hydrazone, the amino nitrogen atom participates in the reaction rather than the imino $\mathrm{N}$ atom despite the latter is a stronger nucleophile than the former from the thermodynamic point of view. Third, the rate limiting step of the whole process is the initial nucleophilic addition via TS5 and TS10, while the further $\mathrm{H}$-transfer step requires very low activation barrier.

Fourth, a distinctive feature of the reaction of the imine with $\mathbf{2}$ is much higher relative stability of INT3 and TS8 ( $\mathrm{sp}^{2} \mathrm{~N}$ nucleophile) compared to INT5 and TS14 $\left(\mathrm{sp}^{2} / \mathrm{sp}^{3} \mathrm{~N}\right.$ nucleophile). INT3 and TS8 are only slightly higher in energy than the initial reactants level (by 4.4 and $7.4 \mathrm{kcal} / \mathrm{mol}$ ), whereas the energies of INT5 and TS14 are comparable with those of the rate limiting TS10 (16.1 and $18.2 \mathrm{kcal} / \mathrm{mol}$ ). Such a difference is accounted for by an extra stabilization of INT3 and TS8 due to the conjugation in the $\mathrm{N}=\mathrm{C}-\mathrm{N}=\mathrm{C}$ fragments and delocalization of electron density. Indeed, the calculated Wiberg bond indices of two $\mathrm{C}=\mathrm{N}$ bonds in INT3 are lower than those in INT5 (1.76 and 1.43 vs. 1.86 and 1.70), and the Wiberg index of the $\mathrm{C}-\mathrm{N}$ bond is higher in INT3 than in INT5 (0.96 vs. 0.79). Correspondingly, the $\mathrm{C}-\mathrm{N}$ bond is noticeably shorter in INT3 than in INT5 (1.45 $⿱$ vs. $1.56 \AA$ ).

Fifth, the Z-isomer of the final products Z-P2 and Z-P3 is more thermodynamically stable than the corresponding E-isomer (by $1.4-3.5 \mathrm{kcal} / \mathrm{mol}$ ). The formation of Z-P2 is both kinetically and thermodynamically controlled. In contrast, for the reaction with hydrazone, Z-P3 is the thermodynamic product, while E-P3 is the kinetic one. There is no experimental data about the structure of the $\mathbf{P 2}$ 
type product. Meanwhile, the E-P3 type product was experimentally isolated and its structure was determined by the X-ray diffraction. A low activation barrier of the E-P3 to Z-P3 isomerization $(10.6 \mathrm{kcal} / \mathrm{mol})$ should permit this process in solution. Therefore, the experimental structural data for E-P3 may be accounted for by an effect of the crystal packing which stabilizes the E-configuration in the solid state due to favorable intermolecular interactions.

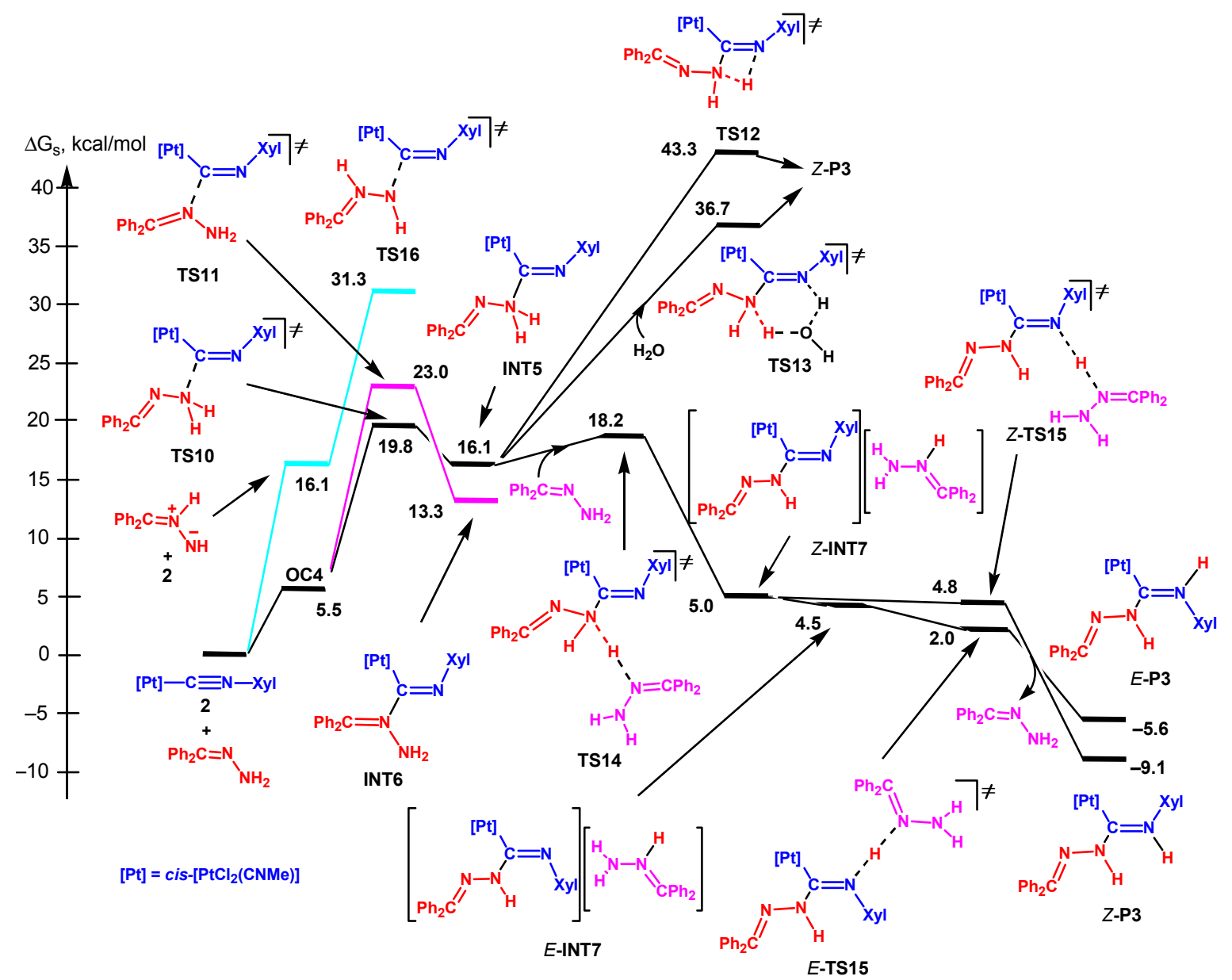

Figure 5. Energy profile for the associative mechanism of nucleophilic addition of $\mathrm{H}_{2} \mathrm{~N}-\mathrm{N}=\mathrm{CPh}_{2}$ to the $\mathrm{C} \equiv \mathrm{NXyl}$ ligand in cis- $\left[\mathrm{PtCl}_{2}(\mathrm{C} \equiv \mathrm{NMe})(\mathrm{C} \equiv \mathrm{NXyl})\right]$.

Sixth, $\Delta \mathrm{G}_{\mathrm{s}}$ of formation of the reaction product with the imine, Z-P2, is only slightly negative $(-1.6 \mathrm{kcal} / \mathrm{mol})$, whereas the final reaction product with the hydrazone, Z-P3, is clearly exoergonic (by $-9.1 \mathrm{kcal} / \mathrm{mol}$ ). This correlates with the experimental detection of unreacted isocyanide in the reaction mixture cis- $\left[\mathrm{PtCl}_{2}(\mathrm{CNXyl})_{2}\right]+\mathrm{HN}=\mathrm{CPh}_{2}$ under synthesis conditions and with the fact that $\mathbf{P} 2$ was not isolated in solid state [95], while the product E-P3 was successfully isolated and characterized [32].

Seventh, the distribution of the Wiberg bond indices in the reaction products $\mathbf{P} \mathbf{2}$ and $\mathbf{P} 3$ indicates that these complexes has an electronic structure intermediate between two resonance forms $\mathbf{a}$ and $\mathbf{b}$ (Figure 6).

Eighth, the overall activation energies of all three reactions discussed above are similar $(19.8-22.4 \mathrm{kcal} / \mathrm{mol})$, demonstrating the low effect of the nitrogen orbital hybridization on the reactivity of the NH-nucleophiles. The kinetic information obtained here for the reactions with imines and hydrazones is particularly important since no experimental kinetic data are available for these processes. 


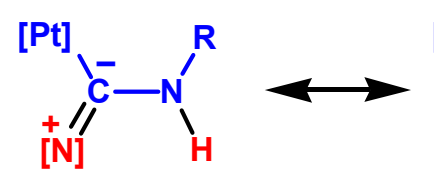

a<smiles>[R][NH+]=C([NH])[In]</smiles>

b<smiles>CNN=CN=N</smiles>

Figure 6. Resonance structures of the nucleophilic addition products.

\section{Final Remarks}

Metal-mediated nucleophilic addition to isocyanides is a very important route toward highly demanding heteroatom-stabilized carbene species. Despite a long history of the investigation of these processes, some important information about the intimate reaction mechanism remained unclear. In this work, a theoretical DFT study has been undertaken with the aim to fill this gap for the reactions of three types of the NH-nucleophiles (i.e., $\mathrm{sp}^{3}-\mathrm{N}, \mathrm{sp}^{2}-\mathrm{N}$, and $\mathrm{sp}^{2} / \mathrm{sp}^{3}-\mathrm{N}$ types) with Pt-bound C $\equiv \mathrm{NR}$. The calculations demonstrated that in all cases the mechanism is stepwise of the associative type (A), and it includes addition of a nucleophile to the isocyanide $\mathrm{C}$ atom, deprotonation of the resulting intermediate (e.g., by the second molecule of a nucleophile or by another base from the reaction mixture), and the protonation of the isocyanide $\mathrm{N}$ atom to give the final product. The nucleophilic addition step is rate limiting for the whole process. The overall activation energy weakly depends on the nucleophile nature and varies from 19.8 to $22.4 \mathrm{kcal} / \mathrm{mol}$. To our knowledge, this is the first estimate of the kinetic parameters for the metal-mediated NA of the $\mathrm{sp}^{2}-\mathrm{N}$ and $\mathrm{sp}^{2} / \mathrm{sp}^{3}-\mathrm{N}$ nucleophiles to isocyanides. Alternative mechanisms (i.e. concerted and dissociative) were found to be not feasible. In the case of hydrazones, which are bifunctional nucleophiles, participation of the amine $\mathrm{N}$ atom is more preferable than the imine $\mathrm{N}$ atom, and the regioselectivity of this reaction is charge-driven.

Supplementary Materials: The following are available online at www.mdpi.com/1420-3049/22/ $7 / 1141 / \mathrm{s} 1$, Figure S1: total energy vs. the $\mathrm{N}-\mathrm{H}$ distance in the systems $\mathrm{H} 2 \mathrm{O} \cdots \mathrm{H}-\mathrm{N}=\mathrm{CPh} 2$, $\mathrm{Ph} 2 \mathrm{C}=(\mathrm{H}) \mathrm{N} \cdots \mathrm{H}-\mathrm{N}=\mathrm{CPh} 2$, Figure S2: total energy vs. the $\mathrm{N}-\mathrm{H}$ distance in the systems $\mathrm{H}_{2} \mathrm{O} \cdots \mathrm{H}-\mathrm{N}(\mathrm{H})-\mathrm{N}=\mathrm{CPh}{ }_{2}$, $\mathrm{Ph}_{2} \mathrm{C}=\left(\mathrm{NH}_{2}\right) \mathrm{N} \cdots \mathrm{H}-\mathrm{N}(\mathrm{H})-\mathrm{N}=\mathrm{CPh}_{2}$, Table S1: calculated total energies, enthalpies, Gibbs free energies, and entropies, Table S2: Cartesian atomic coordinates of the equilibrium structures.

Acknowledgments: The authors are grateful to the Russian Science Foundation (grant 14-43-00017P) for support of this study.

Author Contributions: M.L.K. performed calculations, analyzed the data, and wrote the paper; V.Yu.K. analyzed the data and wrote the paper.

Conflicts of Interest: The authors declare no conflict of interest.

\section{References}

1. Boyarskiy, V.P.; Bokach, N.A.; Luzyanin, K.V.; Kukushkin, V.Yu. Metal-mediated and metal-catalyzed reactions of isocyanides. Chem. Rev. 2015, 115, 2698-2779. [CrossRef] [PubMed]

2. Gulevich, A.V.; Zhdanko, A.G.; Orru, R.V.A.; Nenajdenko, V.G. Isocyanoacetate derivatives: Synthesis, reactivity, and application. Chem. Rev. 2010, 110, 5235-5331. [CrossRef] [PubMed]

3. Hahn, F.E.; Jahnke, M.C. Heterocyclic carbenes: Synthesis and coordination chemistry. Angew. Chem. Int. Ed. 2008, 47, 3122-3172. [CrossRef] [PubMed]

4. Vlaar, T.; Ruijter, E.; Maes, B.U.W.; Orru, R.V.A. Palladium-catalyzed migratory insertion of isocyanides: An emerging platform in cross-coupling chemistry. Angew. Chem. Int. Ed. 2013, 52, 7084-7097. [CrossRef] [PubMed] 
5. Zhu, J.P. Recent developments in the isonitrile-based multicomponent synthesis of heterocycles. Eur. J. Org. Chem. 2003, 7, 1133-1144. [CrossRef]

6. Dömling, A. Recent developments in isocyanide based multicomponent reactions in applied chemistry. Chem. Rev. 2006, 106, 17-89. [CrossRef] [PubMed]

7. Hulme, C.; Lee, Y.-S. Emerging approaches for the syntheses of bicyclic imidazo[1,2-x]-heterocycles. Mol. Divers. 2008, 12, 1-15. [CrossRef] [PubMed]

8. El Kaim, L.; Grimaud, L. Beyond the Ugi reaction: Less conventional interactions between isocyanides and iminium species. Tetrahedron 2009, 65, 2153-2171. [CrossRef]

9. Sadjadi, S.; Heravi, M.M. Recent application of isocyanides in synthesis of heterocycles. Tetrahedron 2011, 67, 2707-2752. [CrossRef]

10. Heravi, M.M.; Moghimi, S. Catalytic multicomponent reactions based on isocyanides. J. Iran. Chem. Soc. 2011, 8, 306-373. [CrossRef]

11. van Berkel, S.S.; Bogels, B.G.M.; Wijdeven, M.A.; Westermann, B.; Rutjes, F.P.J.T. Recent advances in asymmetric isocyanide-based multicomponent reactions. Eur. J. Org. Chem. 2012, 19, 3543-3559. [CrossRef]

12. Ramon, R.; Kielland, N.; Lavilla, R. Recent Progress in Nonclassical Isocyanide-Based MCRs; Wiley-VCH Verlag GmbH \& Co., KGaA.: New York, NY, USA, 2012; p. 299.

13. Lang, S. Unravelling the labyrinth of palladium-catalysed reactions involving isocyanides. Chem. Soc. Rev. 2013, 42, 4867-4880. [CrossRef] [PubMed]

14. Qiu, G.; Ding, Q.; Wu, J. Recent advances in isocyanide insertion chemistry. Chem. Soc. Rev. 2013, 42, 5257-5269. [CrossRef] [PubMed]

15. Suginome, M.; Ito, Y. Transition metal-mediated polymerization of isocyanides. Adv. Polym. Sci. 2004, 171, 77-136. [CrossRef]

16. Gómez, M. (Alkyl)(monocyclopentadienyl)niobium and -tantalum complexes in insertion processes. Eur. J. Inorg. Chem. 2003, 20, 3681-3697. [CrossRef]

17. Antiñolo, A.; Garcıá-Yuste, S.; Otero, A.; Villaseñor, E. On the insertion processes of unsaturated molecules into the $\mathrm{Nb}-\mathrm{X} \sigma$-bond of " $\mathrm{Cp}^{\prime}{ }_{2} \mathrm{NbX}$ " moieties $\left(\mathrm{Cp}^{\prime}=\eta^{5}-\mathrm{C}_{5} \mathrm{H}_{4} \mathrm{SiMe}_{3} ; \mathrm{X}=\mathrm{H}, \mathrm{C}, \mathrm{P}\right)$. J. Organomet. Chem. 2007, 692, 4436-4447. [CrossRef]

18. Lauzon, J.M.P.; Schafer, L.L. Tantallaaziridines: From synthesis to catalytic applications. Dalton Trans. 2012, 41, 11539-11550. [CrossRef] [PubMed]

19. Boyarskiy, V.P.; Luzyanin, K.V.; Kukushkin, V.Yu. Acyclic diaminocarbenes (ADCs) as a promising alternative to N-heterocyclic carbenes (NHCs) in transition metal catalyzed organic transformations. Coord. Chem. Rev. 2012, 256, 2029-2056. [CrossRef]

20. Ito, H.; Kato, T.; Sawamura, M. Design and synthesis of isocyanide ligands for catalysis: Application to Rh-catalyzed hydrosilylation of ketones. Chem. Asian J. 2007, 2, 1436-1446. [CrossRef] [PubMed]

21. Xu, Y.; Hu, X.; Shao, J.; Yang, G.; Wu, Y.; Zhang, Z. Hydration of alkynes at room temperature catalyzed by gold(I) isocyanide compounds. Green Chem. 2015, 17, 532-537. [CrossRef]

22. Liu, M.; Reiser, O. A copper(I) isonitrile complex as a heterogeneous catalyst for azide-alkyne cycloaddition in water. Org. Lett. 2011, 13, 1102-1105. [CrossRef] [PubMed]

23. Ray, S.; Mohan, R.; Singh, J.K.; Samantaray, M.K.; Shaikh, M.M.; Panda, D.; Ghosh, P. Anticancer and antimicrobial metallopharmaceutical agents based on palladium, gold, and silver N-heterocyclic carbene complexes. J. Am. Chem. Soc. 2007, 129, 15042-15053. [CrossRef] [PubMed]

24. Barnard, P.J.; Wedlock, L.E.; Baker, M.V.; Berners-Price, S.J.; Joyce, D.A.; Skelton, B.W.; Steer, J.H. Luminescence studies of the intracellular distribution of a dinuclear gold(I) N-heterocyclic carbene complex. Angew. Chem. Int. Ed. 2006, 45, 5966-5970. [CrossRef] [PubMed]

25. Nolan, S.P.; Navarro, O. C-C bond formation by cross-coupling. In Comprehensive Organometallic Chemistry III, 1st ed.; Canty, A., Ed.; Elsevier: Oxford, UK, 2007; Volume 11, pp. 1-38.

26. Marion, N.; Nolan, S.P. Well-defined N-heterocyclic carbenes-palladium(II) precatalysts for cross-coupling reactions. Acc. Chem. Res. 2008, 41, 1440-1449. [CrossRef] [PubMed]

27. Tskhovrebov, A.G.; Luzyanin, K.V.; Kuznetsov, M.L.; Sorokoumov, V.N.; Balova, I.A.; Haukka, M.; Kukushkin, V.Yu. Substituent R-dependent regioselectivity switch in nucleophilic addition of $\mathrm{N}$-phenylbenzamidine to $\mathrm{Pd}^{\mathrm{II}}$ - and $\mathrm{Pt}^{\mathrm{II}}$-complexed isonitrile $\mathrm{RN} \equiv \mathrm{C}$ giving aminocarbene-like species. Organometallics 2011, 30, 863-874. [CrossRef] 
28. Díez-González, S.; Marion, N.; Nolan, S.P. N-heterocyclic carbenes in late transition metal catalysis. Chem. Rev. 2009, 109, 3612-3676. [CrossRef] [PubMed]

29. Slaughter, L.M. Acyclic aminocarbenes in catalysis. ACS Catal. 2012, 2, 1802-1816. [CrossRef]

30. Kremzow, D.; Seidel, G.; Lehmann, C.W.; Furstner, A. diaminocarbene- and Fischer-carbene complexes of palladium and nickel by oxidative insertion: Preparation, structure, and catalytic activity. Chem. Eur. J. 2005, 11, 1833-1853. [CrossRef] [PubMed]

31. Dhudshia, B.; Thadani, A.N. Acyclic diaminocarbenes: Simple, versatile ligands for cross-coupling reactions. Chem. Commun. 2006, 6, 668-670. [CrossRef] [PubMed]

32. Luzyanin, K.V.; Tskhovrebov, A.G.; Carias, M.C.; Guedes da Silva, M.F.C.; Pombeiro, A.J.L.; Kukushkin, V.Yu. Novel metal-mediated $(\mathrm{M}=\mathrm{Pd}, \mathrm{Pt})$ coupling between isonitriles and benzophenone hydrazone as a route to aminocarbene complexes exhibiting high catalytic activity $(\mathrm{M}=\mathrm{Pd})$ in the Suzuki-Miyaura reaction. Organometallics 2009, 28, 6559-6566. [CrossRef]

33. Slaughter, L. M. Covalent self-assembly of acyclic diaminocarbene ligands at metal centers. Commun. Inorg. Chem. 2008, 29, 46-72. [CrossRef]

34. Moncada, A.I.; Manne, S.; Tanski, J.M.; Slaughter, L.M. Modular chelated palladium diaminocarbene complexes: Synthesis, characterization, and optimization of catalytic Suzuki-Miyaura cross-coupling activity by ligand modification. Organometallics 2006, 25, 491-505. [CrossRef]

35. Bartolomé, C.; Ramiro, Z.; García-Cuadrado, D.; Pérez-Galán, P.; Raducan, M.; Bour, C.; Echavarren, A. M.; Espinet, P. Nitrogen acyclic gold(I) carbenes: Excellent and easily accessible catalysts in reactions of 1,6-enynes. Organometallics 2010, 29, 951-956. [CrossRef]

36. Bartolomé, C.; García-Cuadrado, D.; Ramiro, Z.; Espinet, P. Synthesis and catalytic activity of gold chiral nitrogen acyclic aarbenes and gold hydrogen bonded heterocyclic carbenes in cyclopropanation of vinyl arenes and in intramolecular hydroalkoxylation of allenes. Inorg. Chem. 2010, 49, 9758-9764. [CrossRef] [PubMed]

37. Hashmi, A.S.K.; Hengst, T.; Lothschütz, C.; Rominger, F. New and easily accessible nitrogen acyclic gold(I) carbenes: Structure and application in the gold-catalyzed phenol synthesis as well as the hydration of alkynes. Adv. Synth. Catal. 2010, 352, 1315-1337. [CrossRef]

38. Seo, H.; Snead, D.R.; Abboud, K.A.; Hong, S. Bulky acyclic aminooxycarbene ligands. Organometallics 2011, 30, 5725-5730. [CrossRef]

39. Cavarzan, A.; Scarso, A.; Sgarbossa, P.; Strukul, G.; Reek, J.N.H. Supramolecular control on chemo- and regioselectivity via encapsulation of (NHC)-Au catalyst within a hexameric self-assembled host. J. Am. Chem. Soc. 2011, 133, 2848-2851. [CrossRef] [PubMed]

40. Catalano, V.J.; Etogo, A.O. Preparation of $\mathrm{Au}(\mathrm{I}), \mathrm{Ag}(\mathrm{I})$, and $\mathrm{Pd}(\mathrm{II}) \mathrm{N}$-heterocyclic carbene complexes utilizing a methylpyridyl-substituted NHC ligand. Formation of a luminescent coordination polymer. Inorg. Chem. 2007, 46, 5608-5615. [CrossRef] [PubMed]

41. Bartolomé, C.; Carrasco-Rando, M.; Coco, S.; Cordovilla, C.; Martín-Alvarez, J.M.; Espinet, P. Luminescent gold(I) carbenes from 2-pyridylisocyanide complexes: Structural consequences of intramolecular versus intermolecular hydrogen-bonding interactions. Inorg. Chem. 2008, 47, 1616-1624. [CrossRef] [PubMed]

42. Xue, W.-M.; Chan, M.C.-W.; Su, Z.-M.; Cheung, K.-K.; Liu, S.-T.; Che, C.-M. Spectroscopic and excited-state properties of luminescent rhenium(I) N-heterocyclic carbene complexes containing aromatic diimine ligands. Organometallics 1998, 17, 1622-1630. [CrossRef]

43. Lai, S.-W.; Chan, M.C.-W.; Cheung, K.-K.; Che, C.-M. Carbene and isocyanide ligation at luminescent cyclometalated 6-phenyl-2,2'-bipyridyl platinum(II) complexes: Structural and spectroscopic studies. Organometallics 1999, 18, 3327-3336. [CrossRef]

44. Tschugajeff, L.; Skanawy-Grigorjewa, M. Reaction of $\mathrm{K}_{2} \mathrm{PtCl}_{4}$ with isonitriles and hydrazine. J. Russ. Chem. Soc. 1915, 47, 776.

45. Tschugajeff, L.; Grigorjewa, M.; Posnjak, A. Über die hydrazin-carbilamin-komplexe des platins. Z. Anorg. Allg. Chem. 1925, 148, 37-42. [CrossRef]

46. Rouschias, G.; Shaw, B.L. The chemistry and structure of Chugaev's salt and related compounds Containing a cyclic carbene ligand. J. Chem. Soc. A 1971, 2097-2104. [CrossRef]

47. Burke, A.; Balch, A.L.; Enemark, J.H. Palladium and platinum complex resulting from the addition of hydrazine to coordinated isocyanide. J. Am. Chem. Soc. 1970, 92, 2555-2557. [CrossRef] 
48. Butler, W.M.; Enemark, J.H.; Parks, J.; Balch, A.L. Chelative addition of hydrazines to coordinated isocyanides. Structure of Chugaev's red salt. Inorg. Chem. 1973, 12, 451-457. [CrossRef]

49. Badley, M.; Chatt, J.; Richards, R.L. Isonitrile complexes of platinum(II) and their reactions with alcohols and amines to give carbene complexes. J. Chem. Soc. A 1971, 21-25. [CrossRef]

50. Fehlhammer, W.P.; Bartel, K.; Metzner, R.; Beck, W. Reactions of cationic isocyanide platinum(II) complexes with water (from hexafluoroacetone-hydrate): Carboxamido and isocyanato complexes. Z. Anorg. Allg. Chem. 2008, 634, 1002-1004. [CrossRef]

51. Crociani, B.; Boschi, T.; Belluco, U. Synthesis and reactivity of novel palladium(II)-isocyanide complexes. Inorg. Chem. 1970, 9, 2021-2025. [CrossRef]

52. Michelin, R.A.; Zanotto, L.; Braga, D.; Sabatino, P.; Angelici, R.J. Transition-metal-promoted cyclization reactions of isocyanide ligands. Synthesis of cyclic diaminocarbenes from isocyanide complexes of palladium(II) and platinum(II) and X-ray structure of cis- $\mathrm{Br}_{2} \mathrm{Pt}\left[\mathrm{CN}\left(\mathrm{C}_{6} \mathrm{H}_{4}-p-\mathrm{Me}\right) \mathrm{CH}_{2} \mathrm{CH}_{2} \mathrm{~N}(\mathrm{H})\right]\left(\mathrm{PPh}_{3}\right)$. Inorg. Chem. 1988, 27, 93-99. [CrossRef]

53. Yu, I.; Wallis, C.J.; Patrick, B.O.; Diaconescu, P.L.; Mehrkhodavandi, P. Phosphine-tethered carbene ligands: Template synthesis and reactivity of cyclic and acyclic functionalized carbenes. Organometallics 2010, 29, 6065-6076. [CrossRef]

54. Arias, J.; Bardají, M.; Espinet, P. Luminescence and mesogenic properties in crown-ether-isocyanide or carbene gold(I) complexes: Luminescence in solution, in the solid, in the mesophase, and in the isotropic liquid state. Inorg. Chem. 2008, 47, 3559-3567. [CrossRef] [PubMed]

55. Crociani, B.; Uguagliati, P.; Belluco, U. Steric role of aromatic ring ortho-substituents in the mechanism of carbene formation from palladium(II) arylisocyanide complexes and anilines. J. Organomet. Chem. 1976, 117, 189-199. [CrossRef]

56. Lazar, M.; Zhu, B.; Angelici, R.J. Non-nanogold catalysis of reactions of isocyanides, secondary amines, and oxygen to give ureas. J. Phys. Chem. C 2007, 111, 4074-4076. [CrossRef]

57. Canovese, L.; Visentin, F.; Levi, C.; Bertolasi, V. Synthesis and mechanism of formation of novel NHC-NAC bis-carbene complexes of gold(I). Organometallics, 2011, 30, 875-883. [CrossRef]

58. Ruiz, J.; García, L.; Mejuto, C.; Vivanco, M.; Díaz, M.R.; García-Granda, S. Strong electron-donating metalla-N-heterocyclic carbenes. Chem. Commun. 2014, 50, 2129-2132. [CrossRef] [PubMed]

59. Anding, B.J.; Ellern, A.; Woo, L.K. Comparative study of rhodium and iridium porphyrin diaminocarbene and N-heterocyclic carbene complexes. Organometallics 2014, 33, 2219-2229. [CrossRef]

60. Vicente, J.; Chicote, M.T.; Huertas, S.; Jones, P.G. 1,1-Ethylenedithiolato complexes of palladium(II) and platinum(II) with isocyanide and carbene ligands. Inorg. Chem. 2003, 42, 4268-4274. [CrossRef] [PubMed]

61. Han, Y.; Huynh, H.V. Mixed carbene-isocyanide Pd(II) complexes: Synthesis, structures and reactivity towards nucleophiles. Dalton Trans. 2009, 12, 2201-2209. [CrossRef] [PubMed]

62. Moncada, A.I.; Tanski, J.M.; Slaughter, L.M. Sterically Controlled formation of monodentate versus chelating carbene ligands from phenylhydrazine. J. Organomet. Chem. 2005, 690, 6247-6251. [CrossRef]

63. Martínez-Martínez, A.-J.; Chicote, M.-T.; Bautista, D.; Vicente, J. Synthesis of palladium(II), -(III), and -(IV) complexes with acyclic diaminocarbene ligands. Organometallics 2012, 31, 3711-3719. [CrossRef]

64. Hashmi, A.S.K.; Böhling, C.; Lothschütz, C.; Rominger, F. From isonitriles to carbenes: Synthesis of new NAC - and NHC - palladium(II) compounds and their catalytic activity. Organometallics 2011, 30, 2411-2417. [CrossRef]

65. Heathcote, R.; Howell, J.A.S.; Jennings, N.; Cartlidge, D.; Cobden, L.; Coles, S.; Hursthouse, M. Gold(I)-isocyanide and gold(I)-carbene complexes as substrates for the laser decoration of gold onto ceramic surfaces. Dalton Trans. 2007, 1309-1315. [CrossRef] [PubMed]

66. Bartolomé, C.; Carrasco-Rando, M.; Coco, S.; Cordovilla, C.; Espinet, P.; Martín-Alvarez, J.M. Gold(I)-carbenes Derived from 4-Pyridylisocyanidecomplexes: Supramolecular macrocycles supported by hydrogen bonds, and luminescent behavior. Dalton Trans. 2007, 45, 5339-5345. [CrossRef]

67. Handa, S.; Slaughter, L.M. Enantioselective alkynylbenzaldehyde cyclizations catalyzed by chiral gold(I) acyclic fiaminocarbene complexes containing weak Au-arene interactions. Angew. Chem. Int. Ed. 2012, 51, 2912-2915. [CrossRef] [PubMed]

68. Crespo, O.; Gimeno, M.C.; Laguna, A.; Montanel-Pérez, S.; Villacampa, M.D. Facile synthesis of gold(III) aryl-carbene metallacycles. Organometallics 2012, 31, 5520-5526. [CrossRef] 
69. Bertani, R.; Mozzon, M.; Michelin, R.A. Reactions of aziridine, thiirane, and oxirane with isocyanide ligands in complexes of palladium(II) and platinum(II): Syntheses of neutral five-membered cyclic diamino-, aminothio-, and aminooxycarbene compounds. Inorg. Chem. 1988, 27, 2809-2815. [CrossRef]

70. Uguagliati, P.; Crociani, B.; Belluco, U.; Calligaro, L. Solvent, ligand and temperature effects on the rates of reactions of $\operatorname{cis}$-[ $\left.\mathrm{PdCl}_{2}(\mathrm{CNR})(\mathrm{L})\right]$ with secondary amines. J. Organomet. Chem. 1976, 112, 111-121. [CrossRef]

71. Gonzalez-Fernandez, E.; Rust, J.; Alcarazo, M. Synthesis and reactivity of metal complexes with acyclic (amino) (ylide) carbene ligands. Angew. Chem. Int. Ed. 2013, 52, 11392-11395. [CrossRef] [PubMed]

72. Viguri, M.E.; Huertos, M.A.; Perez, J.; Riera, L. Imidazole-nitrile or imidazole-isonitrile CC coupling on rhenium tricarbonyl complexes. Chem. Eur. J. 2013, 19, 12974-12977. [CrossRef] [PubMed]

73. Kaufhold, O.; Stasch, A.; Pape, T.; Hepp, A.; Edwards, P.G.; Newman, P.D.; Hahn, F.E. Metal template controlled formation of [11] ane- $\mathrm{P}_{2}$ CNHC macrocycles. J. Am. Chem. Soc. 2009, 131, 306-317. [CrossRef] [PubMed]

74. Hahn, F.E.; Tamm, M.; Lügger, T. Equilibrium between isocyanide and carbene complexes in coordination compounds of 2,6-dihydroxyphenyl isocyanide. Angew. Chem. Int. Ed. Engl. 1994, 33, 1356-1359. [CrossRef]

75. Menezes, F.M.C.; Kuznetsov, M.L.; Pombeiro, A.J.L. Isocyanide complexes with platinum and palladium and their reactivity toward cycloadditions with nitrones to form aminooxycarbenes: A theoretical study. Organometallics 2009, 28, 6593-6602. [CrossRef]

76. Novikov, A.S.; Kuznetsov, M.L. Theoretical study of Re(IV) and Ru(II) bis-isocyanide complexes and their reactivity in cycloaddition reactions with nitrones. Inorg. Chim. Acta 2012, 380, 78-89. [CrossRef]

77. Novikov, A.S.; Kuznetsov, M.L.; Pombeiro, A. J. L. Theory of the formation and decomposition of $\mathrm{N}$-heterocyclic aminooxycarbenes through metal-assisted [2+3]-dipolar cycloaddition/retro-cycloaddition. Chem. Eur. J. 2013, 19, 2874-2888. [CrossRef] [PubMed]

78. Kuznetsov, M.L.; Kukushkin, V.Yu. Diversity of reactivity modes upon interplay between Au(III)-bound isocyanides and cyclic nitrones: A theoretical consideration. Dalton Trans. 2017, 46, 786-802. [CrossRef] [PubMed]

79. Herrmann, W.A. N-Heterocyclic carbenes: A new concept in organometallic catalysis. Angew. Chem. Int. Ed. 2002, 41, 1290-1309. [CrossRef]

80. Spallek, M.J.; Riedel, D.; Rominger, F.A.; Hashmi, A.S.K.; Trapp, O. Six-membered, chiral NHCs derived from camphor: Structure-reactivity relationship in asymmetric oxindole synthesis. Organometallics 2012, 31, 1127-1132. [CrossRef]

81. Ruiz, J.; Perandones, B.F.; García, G.; Mosquera, M.E.G. Synthesis of N-heterocyclic carbene complexes of manganese(I) by coupling isocyanide ligands with propargylamines and propargylic alcohols. Organometallics 2007, 26, 5687-5695. [CrossRef]

82. Hashmi, A.S.K.; Lothschütz, C.; Graf, K.; Häffner, T.; Schuster, A.; Rominger, F. A short way to switchable carbenes. Adv. Synth. Catal. 2011, 353, 1407-1412. [CrossRef]

83. Wanniarachchi, Y.A.; Slaughter, L.M. One-step assembly of a chiral palladium bis (acyclic diaminocarbene) complex and its unexpected oxidation to a bis (amidine) complex. Chem. Commun. 2007, 31, 3294-3296. [CrossRef] [PubMed]

84. Wanniarachchi, Y.A.; Slaughter, L.M. Reversible chelate ring opening of a sterically crowded palladium bis(acyclic diaminocarbene) complex. Organometallics 2008, 27, 1055-1062. [CrossRef]

85. Miltsov, S.; Karavan, V.; Boyarsky, V.; Gómez-de Pedro, S.; Alonso-Chamarro, J.; Puyol, M. New acyclic Pd-diaminocarbene catalyst for Suzuki arylation of meso-chlorosubstituted tricarboindocyanine dyes. Tetrahedron Lett. 2013, 54, 1202-1204. [CrossRef]

86. Ryabukhin, D.S.; Sorokoumov, V.N.; Savicheva, E.A.; Boyarskiy, V.P.; Balova, I.A.; Vasilyev, A.V. Catalytic activity of palladium acyclic diaminocarbene complexes in the synthesis of 1,3-Diarylpropynones via Sonogashira reaction: Cross- versus homo-coupling. Tetrahedron Lett. 2013, 54, 2369-2372. [CrossRef]

87. Balch, A.L.; Parks, J.E. Platinum and palladium complexes formed by chelative addition of amines to isocyanides. J. Am. Chem. Soc. 1974, 96, 4114-4121. [CrossRef]

88. Zanella, R.; Boschi, T.; Crociani, B.; Belluco, U. Reactions of palladium(II) isocyanide complexes with bifunctional amines. J. Organomet. Chem. 1974, 71, 135-143. [CrossRef]

89. Zanella, R.; Boschi, T.; Nicolini, M.; Belluco, U. The reactions of bis-isocyanide derivatives of Pd ${ }^{\mathrm{II}}$ with bidentate ligands. J. Organomet. Chem. 1973, 49, C91-C94. [CrossRef] 
90. Michelin, R.A.; Pombeiro, A.J.L.; Guedes da Silva, M.F.C. Aminocarbene complexes derived from nucleophilic addition to isocyanide ligands. Coord. Chem. Rev. 2001, 218, 75-112. [CrossRef]

91. Tamm, M.; Hahn, F.E. Reactions of $\beta$-functional phenyl isocyanides. Coord. Chem. Rev. 1999, 182, $175-209$. [CrossRef]

92. Crociani, B.; Di Bianca, F.; Fontana, A.; Forsellini, E.; Bombieri, G. Nucleophilic attack at Co-ordinated isocyanides promoted by the 2-pyridyl ligand. J. Chem. Soc. Dalton Trans. 1994, 4, 407-414. [CrossRef]

93. Canovese, L.; Visentin, F.; Uguagliati, P.; Crociani, B.; Di Bianca, F. Mechanism of aminocarbene formation by nucleophilic attack on isocyanide ligands in platinum(II) 2-pyrazyl and 4-pyridyl complexes. J. Organomet. Chem. 1997, 535, 69-75. [CrossRef]

94. Canovese, L.; Visentin, F.; Uguagliati, P.; Crociani, B. Mechanism of formation of (methoxy)(amino)-And bis(amino) carbene complexes by nucleophilic attack of methoxide ion and amines on platinum(II)-coordinated isocyanide in anhydrous methanol. J. Organomet. Chem. 1997, 543, 145-151. [CrossRef]

95. Luzyanin, K.V.; Guedes da Silva, M.F.C.; Kukushkin, V.Y.; Pombeiro, A.J.L. First example of an imine addition to coordinated isonitrile. Inorg. Chim. Acta. 2009, 362, 833-838. [CrossRef]

96. Zhao, Y.; Truhlar, D.G. A new local density functional for main-group thermochemistry, transition metal bonding, thermochemical kinetics, and noncovalent interactions. J. Chem. Phys. 2006, 125, 194101-194118. [CrossRef] [PubMed]

97. Frisch, G.W.; Trucks, H.B.; Schlegel, G.E.; Scuseria, M.A.; Robb, J.R.; Cheeseman, G.; Scalmani, V.; Barone, B.; Mennucci, G.A.; Petersson, H.; et al. Gaussian 09; Revision A.01; Gaussian, Inc.: Wallingford, CT, USA, 2009.

98. Andrae, D.; Haussermann, U.; Dolg, M.; Stoll, H.; Preuss, H. Energy-adjusted ab initio pseudopotentials for the second and third row transition elements. Theor. Chim. Acta 1990, 77, 123-141. [CrossRef]

99. Marenich, A.V.; Cramer, C.J.; Truhlar, D.G. Universal solvation model based on solute electron density and a continuum model of the solvent defined by the bulk dielectric constant and atomic surface tensions. J. Phys. Chem. B 2009, 113, 6378-6396. [CrossRef] [PubMed]

100. Gonzalez, C.; Schlegel, H.B. Improved algorithms for reaction path following: Higher-order implicit algorithms. J. Chem. Phys. 1991, 95, 5853-5860. [CrossRef]

101. Gonzalez, C.; Schlegel, H.B. An improved algorithm for reaction path following. J. Chem. Phys. 1989, 90, 2154-2161. [CrossRef]

102. Gonzalez, C.; Schlegel, H.B. Reaction path following in mass-weighted internal coordinates. J. Phys. Chem. 1990, 94, 5523-5527. [CrossRef]

103. Wiberg, K.B. Application of the Pople-Santry-Segal CNDO method to the cyclopropylcarbinyl and cyclobutyl cation and to bicyclobutane. Tetrahedron 1968, 24, 1083-1096. [CrossRef]

104. Reed, A.E.; Curtiss, L.A.; Weinhold, F. Intermolecular interactions from a natural bond orbital, donor-acceptor viewpoint. Chem. Rev. 1988, 88, 899-926. [CrossRef]

105. Lasri, J.; Kuznetsov, M.L.; Guedes da Silva, M.F.C.; Pombeiro, A.J.L. Pt ${ }^{\mathrm{II}}$-mediated imine-nitrile coupling leading to symmetrical (1,3,5,7,9-pentaazanona-1,3,6,8-tetraenato) $\mathrm{Pt}(\mathrm{II})$ complexes containing the incorporated 1,3-diiminoisoindoline moiety. Inorg. Chem. 2012, 51, 10774-10786. [CrossRef] [PubMed]

Sample Availability: Not Avaiable. 